\title{
IDENTIFICATION OF NONLINEAR SYSTEMS BY USING ELLIPTIC AND LOXODROMIC METHODS
}

\author{
V.P. Shcherbakov, vs_develop@mail.ru, \\ A.A. Andreeva, anafrens@bk.ru \\ South Ural State University, Chelyabinsk, Russian Federation
}

\begin{abstract}
This article describes the results of using elliptic and loxodromic methods for identification of nonlinear systems with applying of the distributed computing and Acsocad software. Presents the existing methods for identification of objects and systems in the time domain, and also describes standard methods and identification algorithms by using Acsocad. The research of nonlinear objects with two and three unknown parameters are done. For their identification the methods of global minimum search by ellipse and spiral for two-dimensional case and with using ellipsoid and loxodromic curves for three-dimensional case are developed. This article describes the results of researches, which contain the parameters estimation error, standard deviation, the number of performed operations, and also the map of the global minimum search.

Keywords: identification, nonlinear system, elliptic method, loxodromic method, distributed computing, Acsocad.
\end{abstract}

\section{Introduction}

A common application of the computing techniques using distributed computing allows for the efficient solutions of the complicated design, production, and scientific-research problems [1]. One of the main advantages of the distributed computing systems is a high speed of the similar calculations for different data sets [2], which makes it possible to use them in solving the tasks of control, design, predicting, diagnostics, and identification [3-5].

To solve the problem of parameter identification for the elements of the linear systems almost instantaneously, the Kalman filter is generally used. However, the Kalman filter often cannot provide with an adequate parameter valuation for the nonlinear systems especially those described by a complex mathematical model [6-8].

In this case, it seems advisable to use the suggested approach [9] of estimating the mean square deviation (MSD) of the received output signal from the known output signal of the system. Then, according to the model of the nonlinear system being studied, the software code with a build-in table of the known signal values is created in general terms with a set of hypothetical parameter values as the input data of computation procedure. The investigated nonlinear system with the set-up parameters will be simulated as a result of the code execution, and the received output signal of the system will be used to estimate the MSD and make decision of the following looking for the new supposed system parameters.

The described method is implemented in Acsocad software solution, which includes simulation and identification tools SimACS as well as identification programs for the linear systems in the time ItACS and frequency IfACS domains. An important benefit of the identification in SimACS is a possibility of simulating the systems with the random interelement coupling, and applying both multithreading-based distributed systems and those using modern OpenCL technology for identification. Besides, the software has a feature of creating its own identification methods as well as a possibility of developing its own identification algorithm based on these methods.

\section{Identification methods and algorithms}

Today, a great number of methods of a global MSD minimum search has been developed. However, in order to achieve the acceptable results of identification, a combination of methods with different features should be used which is implemented as an identification algorithm in the software. In this case, the identification methods in Acsocad product can be divided into three classes, such as the start points definition methods, grouping methods, and methods of a global minimum search. 


\section{Краткие сообщения}

The first class of the methods allows defining a list of parameter (point) sets describing a certain region, which is expected to contain the desired global minimum. Such methods have no need of information about the previous points, so they can be used independently with a maximum computational speed. They include random and uniform fill methods, elliptic method, loxodromic method, and the others.

The second class of the methods allows grouping of the previously obtained points into the areas and receiving an additional point list, which helps to define a global minimum quickly. This class includes the geometrical method based on the concepts of the geolocation method with the desired point determination according to the data on the distances and locations of the other points.

The third class of the methods is oriented to a search for a global minimum according to the previously obtained points. This class contains the explorer method using the ideas of the gradient method of descent with the accelerated motion to the MSD minimum while a search is executed for different points simultaneously.

\section{Studying an object with two unknown parameters}

To make a comparative study of the identification methods, an experiment with a technical object was carried out. By signaling $\cos (t)$, the output signal with a noise in the time domain was obtained, recorded with an apparatus, and put in a file. The investigated technical object has a mathematical model presented in Acsocad product as a block diagram (Fig. 1) with two unknown parameters $P 0$ and $P 1$.

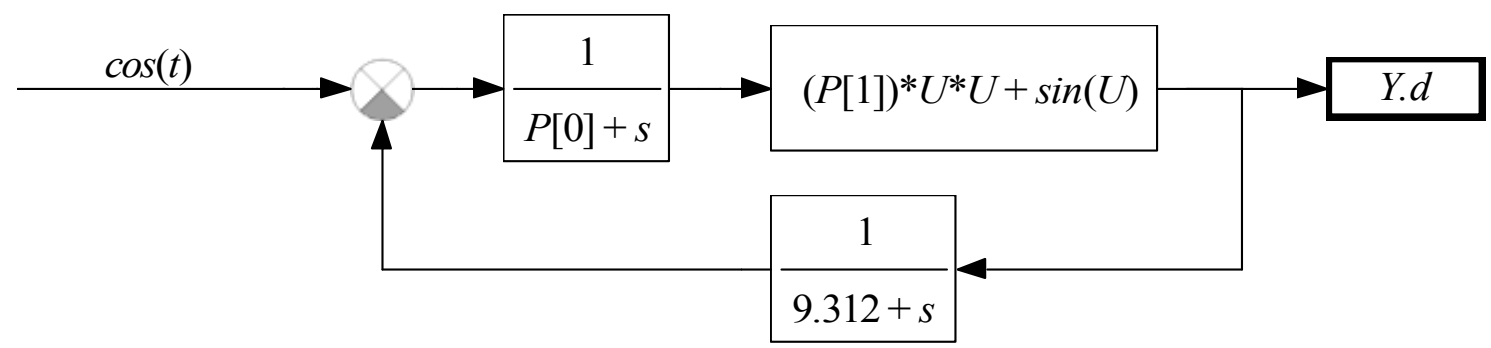

Fig. 1. The block diagram of the investigated object with two parameters

The real values of two unknown parameters are equal to 3.751 and 7.283 respectively. An output signal $Y(t)$ has been measured within two seconds with a step of $0.1 \mathrm{c}$. The time dependence of output signal value is shown in Fig. 2.

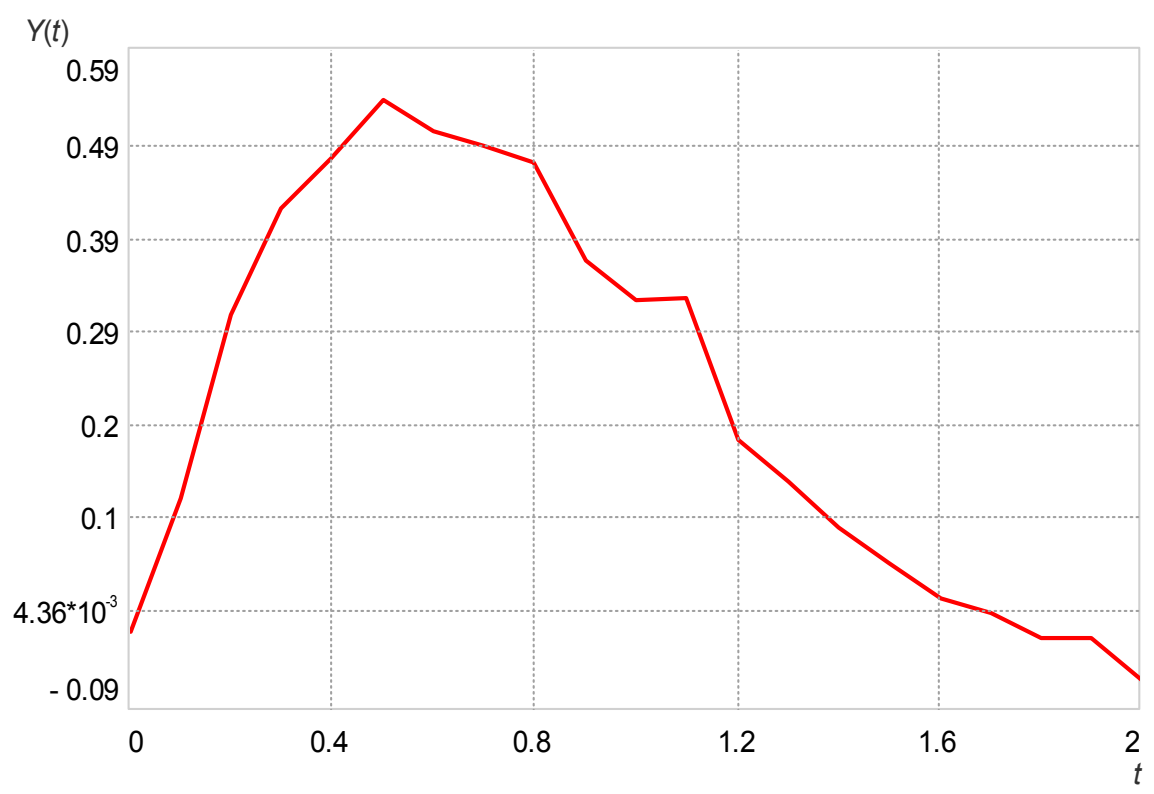

Fig. 2. The time dependence of output signal of the investigated system 
To identify nonlinear system in Acsocad, two unknown parameters are to be set up in the identification tab and a range is defined, in which the target parameters can vary. The range of $P 0$ parameter search is selected from 0 to 10 , and of $P 1$ one is from 0 to 20 .

After that, the accessible platforms enabling computation are selected in Acsocad product and the specified platform usage factor is pointed out. Consequently, it is possible to make calculations by using video card for computing a packet of 10 points, for example, and to engage additionally the processor cores for computing the packets with a few number of points. Such an approach allows selecting time-optimal method of computation distributing for each specific computer configuration.

An Acsocad dialogue box with the identification tab set and test results of the identification is shown in Fig. 3.

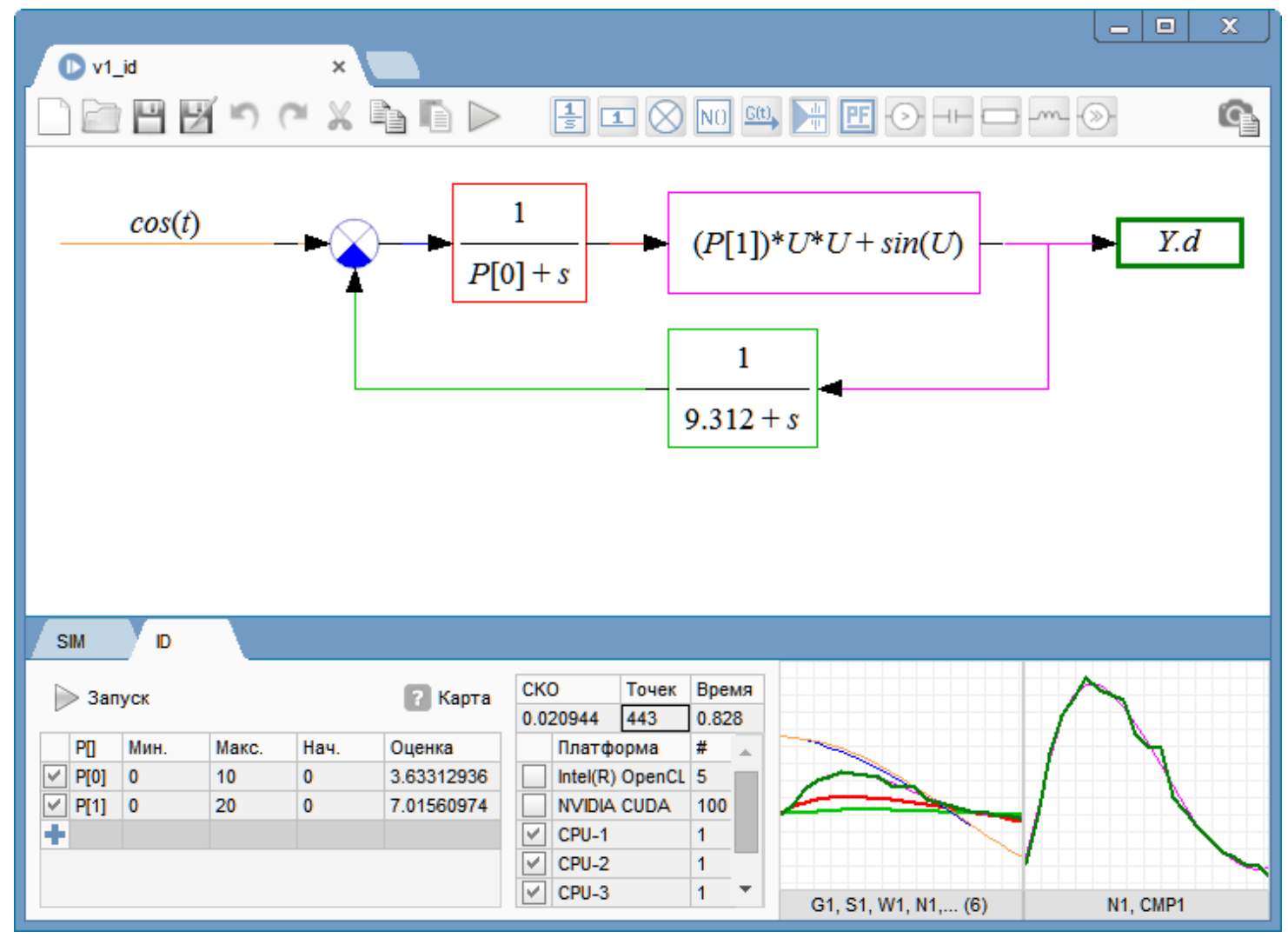

Fig. 3. The Acsocad dialogue box

The identification executed in Acsocad product by means of standard algorithm, which involves the uniform fill method with a following global MSD minimum search by three explorers, resulted in a computation of 443 points and obtaining the model parameters 3.633 and 7.015 as well as the MSD value equal to 0.0209 .

The maximum relative error was $3.7 \%$ for estimating $P 0$ parameter. The global minimum search map is shown in Fig. 4.

The random fill method based on using the normal law of distribution for initial points search allowed to obtain 575 points, and the model parameters equal to 3.671 and 7.184 as well as MSD equal to 0.0209 by mean of random sampling of 200 points with the following running the explorers. The maximum relative error was $2.1 \%$ for estimating $P 0$ parameter. The global minimum search map is shown in Fig. 5.

However, along with the uniform and random fill methods, the elliptic and loxodromic methods were developed. Their accuracy and speed indices turned out to be quit different.

The elliptic method permitted to estimate the values of parameters as 3.669 and 7.185 by computing 284 points and calculate MSD equal to 0.0209 . The maximum relative error was $2.2 \%$ for estimating $P 0$ parameter. The global minimum search map is shown in Fig. 6. 


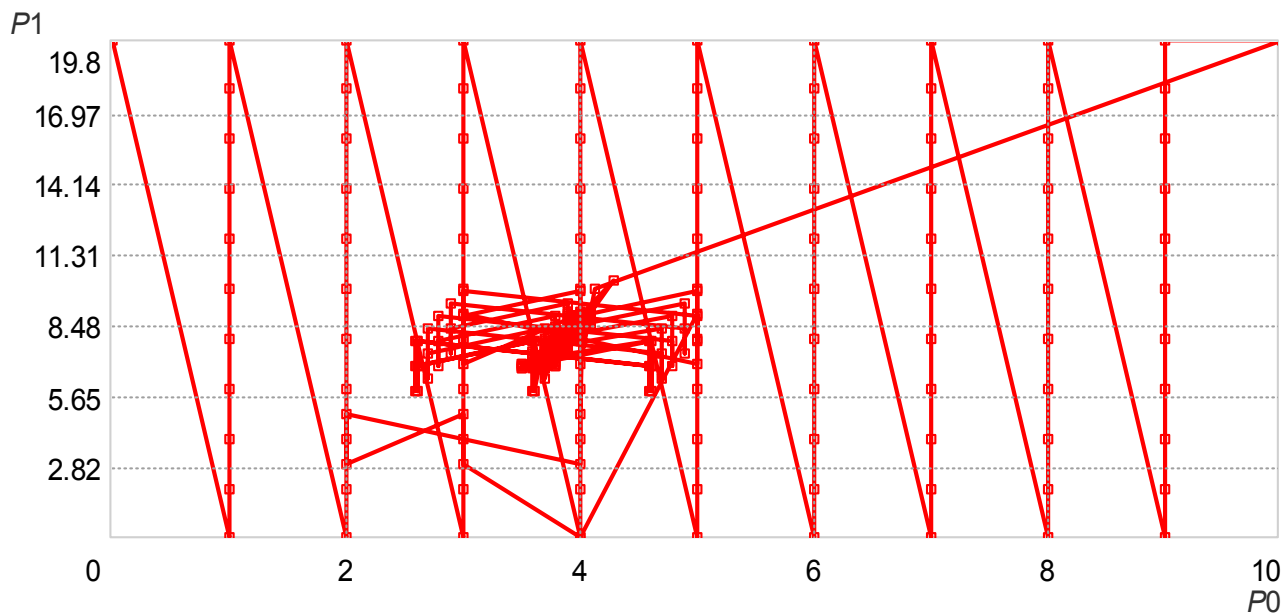

Fig. 4. The minimum search map obtained using the uniform fill method

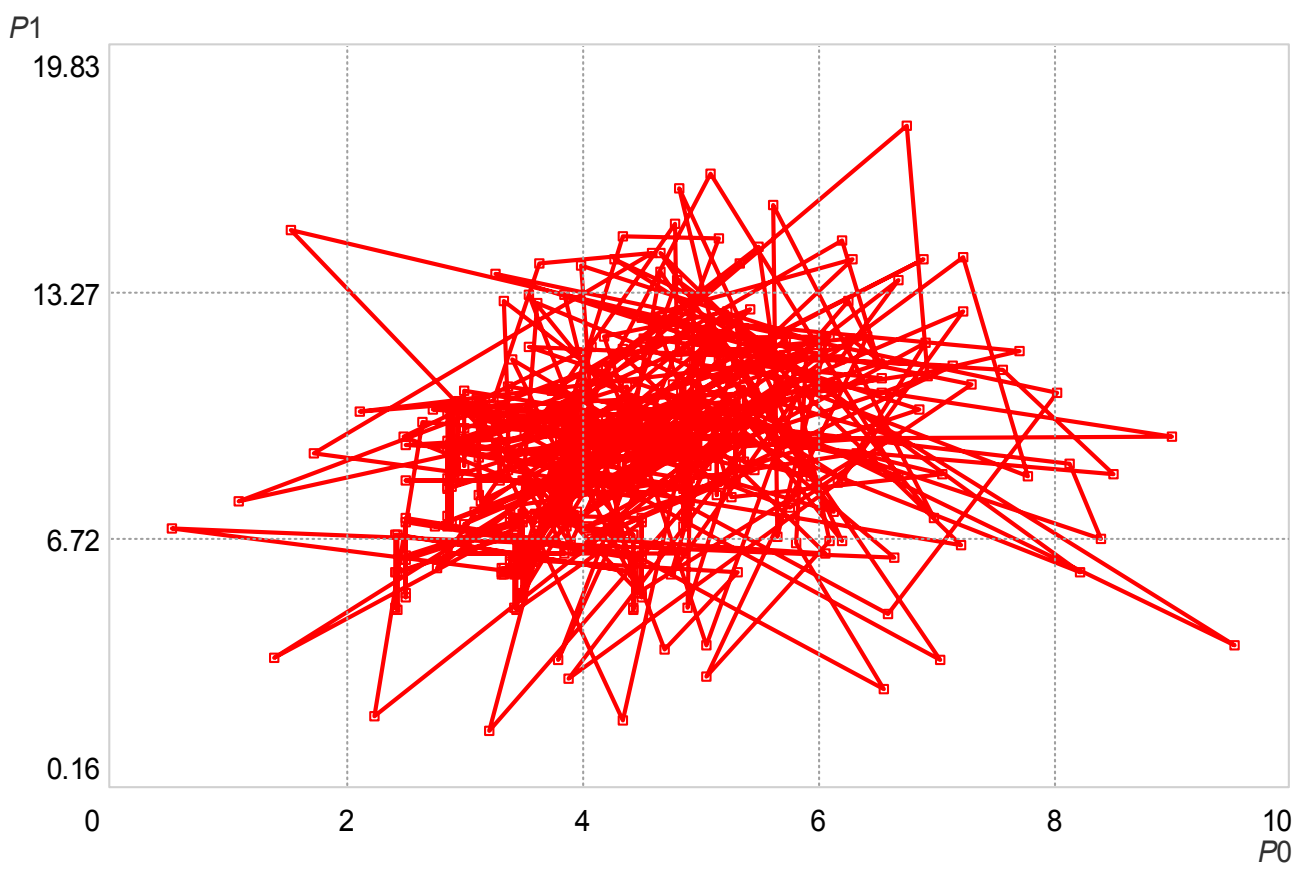

Fig. 5. The minimum search map obtained using the random fill method

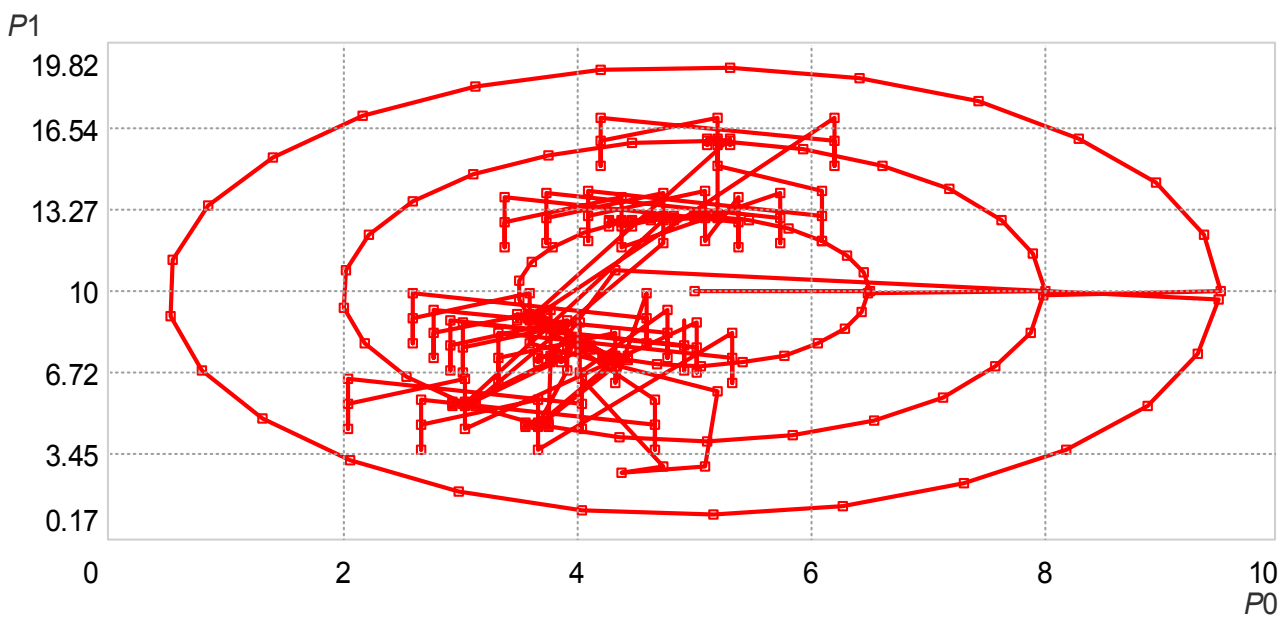

Fig. 6. The minimum search map obtained by elliptic method 
In two-dimensional space, the loxodromic method can be represented as a spiral distribution [10] beginning in a centre of a parameter search range, and finishing on boundary values of these ranges.

The values of parameters were estimated as 3.733 and 7.139 by computing 398 points and MSD was calculated equal to 0.022 . The maximum relative error was $1.9 \%$ for estimating $P 0$ parameter. The global minimum search map is shown in Fig. 7.

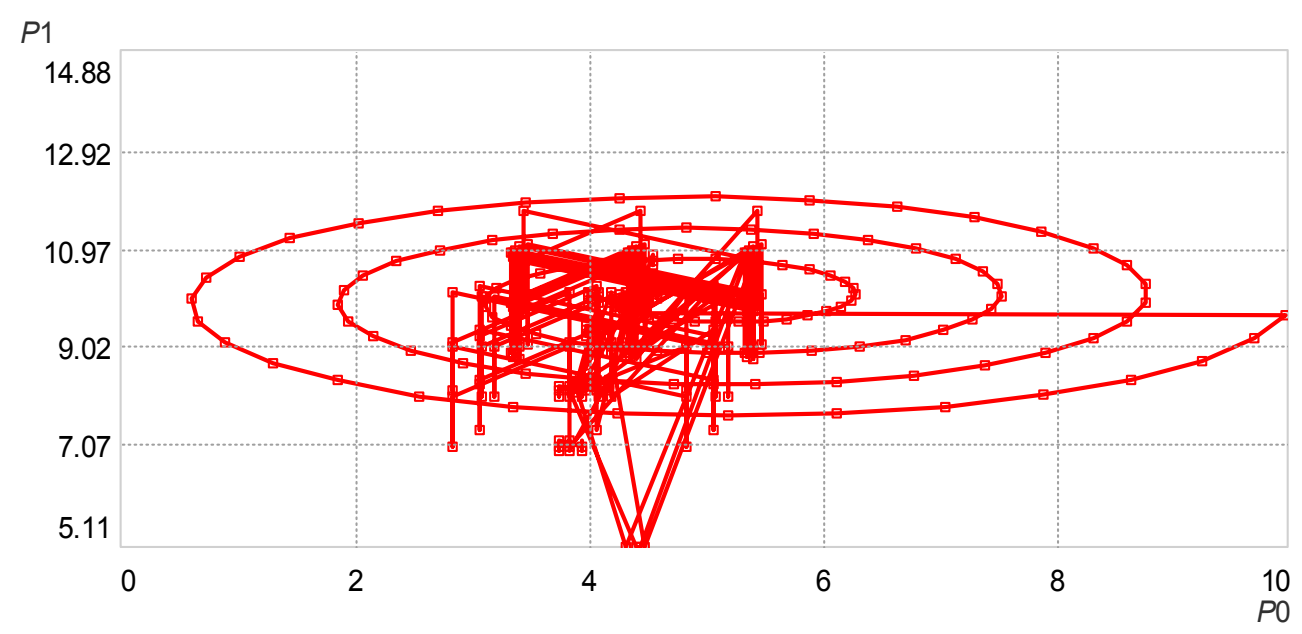

Fig. 7. The minimum search map obtained by loxodromic method

Thus, in two-dimensional space, the elliptic and loxodromic methods provide the results of identification with the maximum relative error of the parameters estimating which is less with respect to the maximum error of the uniform fill method by $1.5 \%$.

Studying an object with three unknown parameters

A block diagram of a technical object with three unknown parameters is given in Fig. 8.

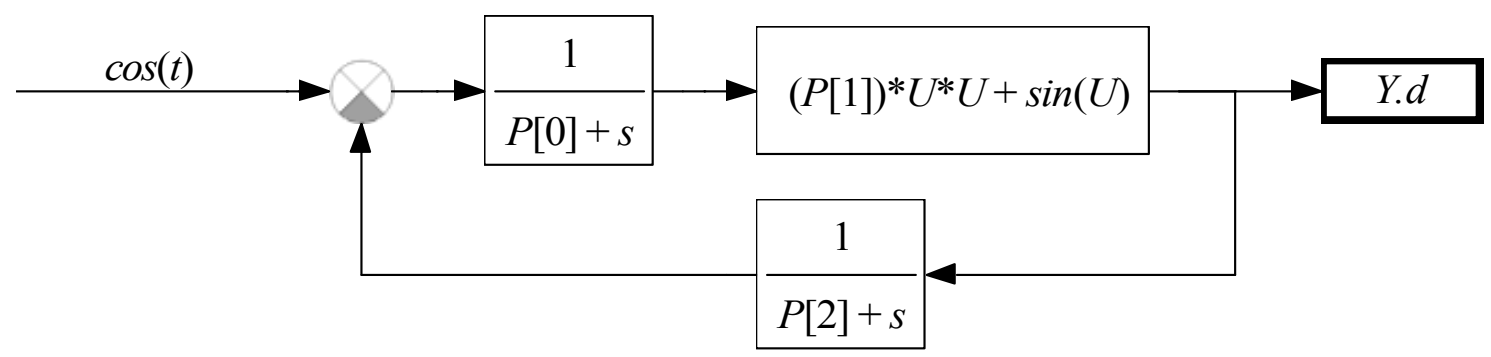

Fig. 8. The block diagram of investigated object with three parameters

The real values of the first two parameters were equal to 3.751 and 7.283 and the value of the third parameter was 9.312. After that, a setting for three unknown system parameters was done in Acsocad software and a search for the third parameter ranged from 0 to 20 .

After the identification, 589 points were calculated by standard algorithm and the model parameters were obtained equal to $3.986,8.278$ и 13.907 . The MSD value was estimated equal to 0.0223 . The maximum relative error was $49 \%$ for estimating $P 2$ parameter. The global minimum search map obtained by uniform fill method is shown in Fig. 9.

An application of the random fill method permitted to obtain 900 points and the model parameters equal to $3.359,6.426$, and 5.411 and the MSD value of 0.0209 by random sampling of 100 points with the following running the explorers. The maximum relative error was $42 \%$ for estimating $P 2$ parameter. The global minimum search map is shown in Fig. 10. 


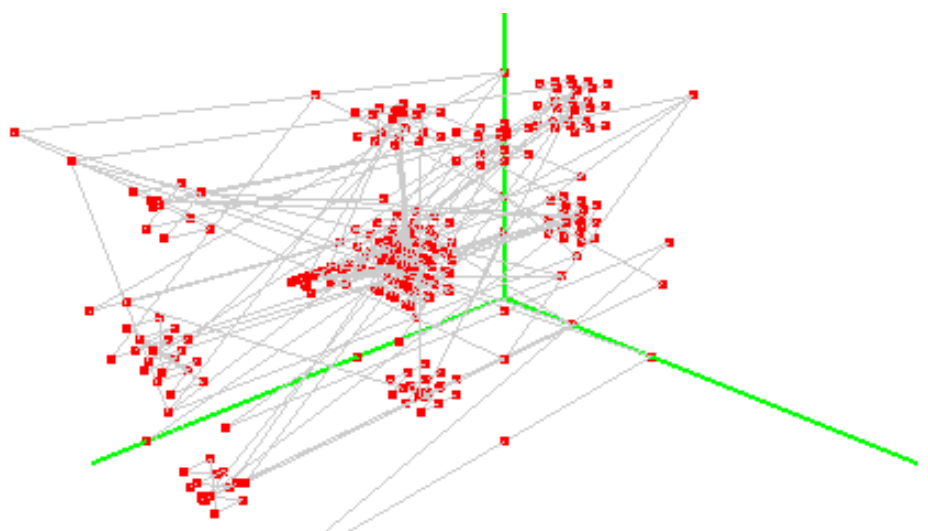

Fig. 9. The minimum search map obtained by uniform fill method

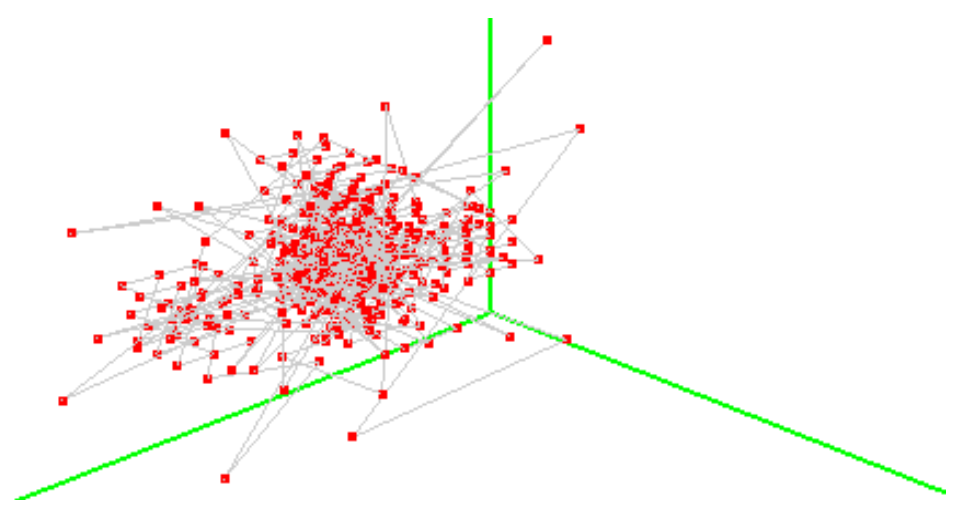

Fig. 10. The minimum search map obtained by random fill method

After the identification by using elliptic method, the parameters $3.622,6.986$, and 8.877 were estimated by calculating 1694 points and the MSD value was computed equal to 0.0209 . The maximum relative error was $4.7 \%$ for estimating $P 2$ parameter. The global minimum search map for the elliptic method is shown in Fig.11.

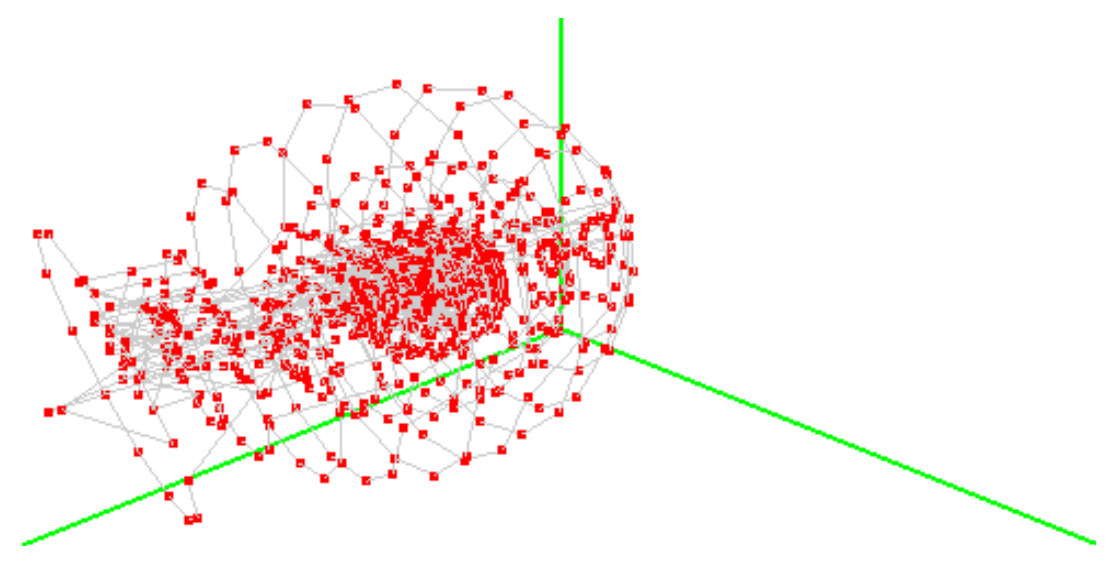

Fig. 11. The global minimum search map for the elliptic method

By mean of loxodromic method plotting a loxodrome in three-dimensional space, the parameters $3.81,7.564$, and 10.883 were estimated by calculating 1196 points and the MSD value was computed equal to 0.021 . The maximum relative error was $17 \%$ for estimating $P 2$ parameter. The global minimum search map for the loxodromic method is shown in Fig. 12. 


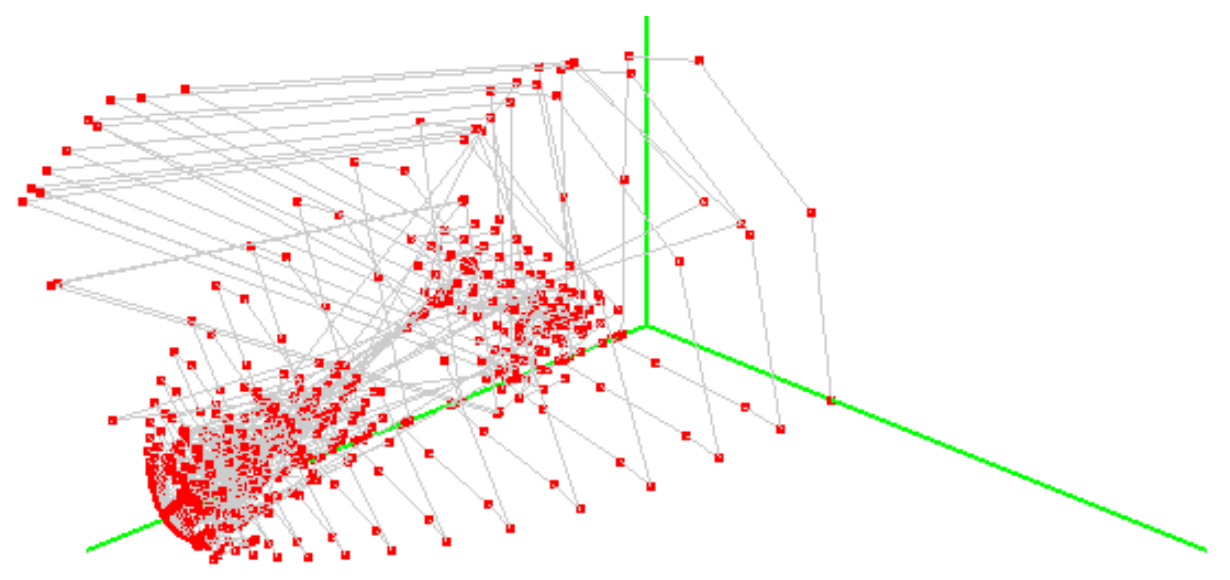

Fig. 12. The global minimum search map for the loxodromic method

Thus, in three-dimensional space, the elliptic and loxodromic methods provide the results of identification with the maximum error of the parameters estimating which is less with respect to the maximum error of the uniform fill method by $32 \%$.

\section{A comparative performance evaluation of the methods}

The characteristics of the methods applied towards the identification of non-linear systems with two and three unknown parameters are given in Table 1.

Table 1

The results of non-linear systems identification with two and three parameters

\begin{tabular}{|l|c|c|c|c|}
\hline \multirow{2}{*}{$\begin{array}{c}\text { Identification } \\
\text { method }\end{array}$} & \multicolumn{2}{|c|}{ Two parameters } & \multicolumn{2}{c|}{ Three parameters } \\
\cline { 2 - 5 } & $\begin{array}{c}\text { Number } \\
\text { of points }\end{array}$ & Error, \% & $\begin{array}{c}\text { Number } \\
\text { of points }\end{array}$ & Error, \% \\
\hline Uniform fill & 443 & 3,7 & 589 & 49 \\
\hline Random fill & 575 & 2,1 & 900 & 42 \\
\hline Elliptic & 284 & 2,2 & 1694 & 4,7 \\
\hline Loxodromic & 398 & 1,9 & 1196 & 17 \\
\hline
\end{tabular}

\section{Conclusion}

The elliptic and loxodromic methods can be applied successfully towards the identification of nonlinear systems while using distributed computing.

\section{References}

1. Gaster B., Howes L., Kaeli D.R., Mistry P., Schaa D. Heterogeneous Computing with OpenCL (Revised OpenCL 1.2 Edition). Morgan Kaufmann, 2012. 308 p.

2. Scarpino M. OpenCL in Action: How to Accelerate Graphics and Computations. Manning Publications, 2011. $458 \mathrm{p}$.

3. Banger R., Bhattacharyya K. OpenCL Programming by Example (+ source code). Packt Publishing, 2013. $304 \mathrm{p}$.

4. Cheng J., Grossman M., McKercher T. Professional CUDA C Programming. - N.-Y.: Wrox, 2014. $528 \mathrm{p}$.

5. Wilt N. The CUDA handbook. A Comprehensive Guide to GPU Programming. Pearson Education, Inc., 2013. 522 p.

6. Epashnikov V.D., Perlovskiy E.V. [Parametrical Identification of Continuous Systems of Automatic Control]. Electronic Scientific Publication "Scientific Notes PNU”, 2013, vol. 4, no. 4, pp. 834-840. (in Russ.)

7. Tsibizova T.Yu. [Identification of Nonlinear Systems of Automatic Control by Means of Voltaire's Filters]. Basic Researches, 2015, no. 2-14, pp. 3070-3074. (in Russ.) 


\title{
Краткие сообщения
}

8. Tsibizova T.Yu. [Methods of Identification of Nonlinear Control Systems] Modern Problems of Science and Education, 2015, no. 1-1. Available at: http://www.science-education.ru/ru/article/ view?id=17910 (accessed 01.06.2016).

9. Shcherbakov V.P. [Method of Simulating Identification for Estimating Frequency Response of Objects and Systems]. Proc. "Mechanics and Control Processes". Moscow, RAS, 2011, pp. 238-245.

10. Weintrit A., Kopacz P. A Novel Approach to Loxodrome (Rhumb-Line), Orthodrome (Great Circle) and Geodesic Line in ECDIS and Navigation in General. Methods and Algorithms in Navigation, Marine Navigation and Safety of Sea Transportation. Leiden: A Balkema Book, CRC Press, Taylor \& Francis Grup, 2011, pp. 123-132.

Received 10 May 2016

\section{ИДЕНТИФИКАЦИЯ НЕЛИНЕЙНЫХ СИСТЕМ С ИСПОЛЬЗОВАНИЕМ ЭЛЛИПТИЧЕСКИХ И ЛОКСОДРОМИЧЕСКИХ МЕТОДОВ}

\author{
В.П. Щербаков, А.А. Андреева \\ Южно-Уральский государственный университет, г. Челябинск
}

\begin{abstract}
Рассматриваются результаты использования эллиптических и локсодромических методов для идентификации нелинейных систем с применением распределенных вычислений и программного комплекса Acsocad. Представлены существующие способы идентификации объектов и систем во временной области, а также описаны стандартные методы и алгоритмы идентификации с применением Acsocad. Проведено исследование нелинейных объектов, которые имеют два и три неизвестных параметра. Для их идентификации разработаны методы поиска глобального минимума при помощи эллипсов и спирали для двумерного случая, а также эллипсоидом и локсодромой для трехмерного случая. В статье представлены результаты исследований, которые состоят из значения погрешности оценки параметров, среднеквадратичного отклонения, количества выполненных операций, а также карты поиска глобального минимума.

Ключевые слова: идентификация, нелинейная система, эллиптический метод, локсодромический метод, распределенные вычисления, Acsocad.
\end{abstract}

\section{Лumepamypa}

1. Heterogeneous Computing with OpenCL (Revised OpenCL 1.2 Edition) / B. Gaster, L. Howes, D.R. Kaeli et al. - 2nd revised edition. - Morgan Kaufmann, 2012. -308 p.

2. Scarpino, M. OpenCL in Action: How to Accelerate Graphics and Computations / M. Scarpino. Manning Publications, 2011. - 458 p.

3. Banger, R. OpenCL Programming by Example (+ source code) / R. Banger, K. Bhattacharyya. Packt Publishing, 2013. - 304 p.

4. Cheng, J. Professional CUDA C Programming / J. Cheng, M. Grossman, T. McKercher. - N.-Y.: Wrox. $-2014 .-528 p$.

5. Wilt, N. The CUDA handbook. A Comprehensive Guide to GPU Programming / N. Wilt. - Pearson Education, Inc., 2013. - 522 p.

6. Епанешников, В.Д. Параметрическая идентификаиия непрерывных систем автоматического регулирования / В.Д. Епанешников, Е.В. Перловский // Электронное научное издание «Ученые заметки ТОГУ». - 2013. - Том 4. - № 4. - С. $834-840$.

7. Цибизова, Т.Ю. Идентификачия нелинейных систем автоматического управления при помощи фильтров Вольтерра / Т.Ю. Цибизова // Фундаментальные исследования. - 2015. - № 2-14. C. 3070-3074. - http://www.fundamental-research.ru/ru/article/view?id=37693 (дата обрамения: 01.06.2016). 
8. Цибизова, Т.Ю. Методы идентификачии нелинейных систем управления / Т.Ю. Цибизова // Современные проблемы науки и образования. - 2015. - № 1-1. - http://www.science-education.ru/ru/ article/view? id=17910 (дата обращения: 01.06.2016).

9. Щербаков, В.П. Метод идентификаџии моделированием для получения частотной характеристики объектов и систем // Сборник научных трудов "Механика и процессы управления» / В.П. Щербаков. - М.: РАН, 2011. - С. 238-245.

10. Weintrit, A. A Novel Approach to Loxodrome (Rhumb-Line), Orthodrome (Great Circle) and Geodesic Line in ECDIS and Navigation in General / A. Weintrit, P. Kopacz // Methods and Algorithms in Navigation, Marine Navigation and Safety of Sea Transportation. Leiden: A Balkema Book, CRC Press, Taylor \& Francis Grup, 2011. - pp. 123-132.

Щербаков Василий Петрович, старший преподаватель кафедры систем управления, ЮжноУральский государственный университет, г. Челябинск; vs_develop@mail.ru.

Андреева Анастасия Андреевна, магистрант кафедры систем управления, Южно-Уральский государственный университет, г. Челябинск; anafrens@bk.ru.

Поступила в редакцию 10 мая 2016 г.

\section{ОБРАЗЕЦ ЦИТИРОВАНИЯ}

Shcherbakov, V.P. Identification of Nonlinear Systems by Using Elliptic and Loxodromic Methods / V.P. Shcherbakov, А.A. Andreeva // Вестник ЮУрГУ. Серия «Компьютерные технологии, управление, радиоэлектроника». - 2016. - Т. 16, № 3. - С. 159-167. DOI: $10.14529 / \operatorname{ctcr} 160318$

\section{FOR CITATION}

Shcherbakov V.P., Andreeva A.A. Identification of Nonlinear Systems by Using Elliptic and Loxodromic Methods. Bulletin of the South Ural State University. Ser. Computer Technologies, Automatic Control, Radio Electronics, 2016, vol. 16, no. 3, pp. 159-167. DOI: $10.14529 /$ ctcr 160318 